J Am Chem Soc. 2016 August 24; 138(33): 10684-10692. doi:10.1021/jacs.6b06460.

\title{
A Concise Total Synthesis of Dictyodendrins F, H, and I Using Aryl Ynol Ethers as Key Building Blocks
}

\author{
Wenhan Zhang and Joseph M. Ready ${ }^{\star}$ \\ Department of Biochemistry, University of Texas Southwestern Medical Center, 5323 Harry Hines \\ Boulevard, Dallas, Texas 75390
}

\section{Abstract}

We report a concise total synthesis of dictyodendrin $\mathrm{F}$ and the first total syntheses of dictyodendrins $\mathrm{H}$ and I in six steps. In these syntheses, aryl ynol ethers were employed as the key building blocks to introduce aryl and heteroaryl rings in the dictyodendrins. This rapid synthesis utilized a novel hetero-[2+2]-cycloaddition reaction between two aryl ynol ethers to yield a cyclobutenone ring. The cyclobutenone was sequentially converted into a highly substituted carbazole via a retro- $4 \pi / 6 \pi$-electrocyclization- $N$-acylation cascade reaction to provide the dictyodendrin core. Consecutive intramolecular oxidative coupling and deprotection gave dictyodendrins $\mathrm{F}, \mathrm{H}$, and $\mathrm{I}$.

\section{Introduction}

Fusetani and co-workers isolated dictyodendrins A-E from the marine sponge dictyodendrilla verongiformis in 2003 in a search for inhibitors of telomerase. ${ }^{1,2}$ In 2012, Capon and co-workers discovered dictyodendrins F-J from the Ianthella sponge and showed that they were moderately potent inhibitors of $\beta$-site amyloid-cleaving enzyme 1 (BACE1), ${ }^{3}$ a potential target for treating Alzheimer's disease. ${ }^{4}$ Because of their unique structure and intriguing biological activities, the dictyodendrins are popular targets for synthetic chemists. Structurally, dictyodendrins contain a highly substituted pyrrolo[2,3-c]carbazole core ${ }^{5}$ at the phenol or quinone oxidation state. The Fürstner group reported the first syntheses of dictyodendrins B, C, E, and F (Figure 1, 2-5) in 2005 and 2006. Additionally, they demonstrated the DNA-cleaving activity of dictyodendrins and their analogs. ${ }^{6}$ Subsequently, five other groups have disclosed their synthetic strategies towards this natural product family. ${ }^{5,7}$ Tokuyama and co-workers developed a general and flexible synthetic approach targeting dictyodendrins A-E, but their synthesis involved 21-22 linear steps. ${ }^{8}$ Recently, the development of $\mathrm{C}-\mathrm{H}$ activation methods has enabled the efficient syntheses of these natural products. Gaunt, ${ }^{9}$ Davies, ${ }^{10}$ and Jia ${ }^{11}$ groups disclosed elegant syntheses of several dictyodendrins using $\mathrm{C}-\mathrm{H}$ functionalization strategies in 9-13 synthetic steps. ${ }^{12}$ Currently, dictyodendrins $\mathrm{H}$ and I (Figure 1, 6, 7) have not been synthesized. These two dictyodendrins

*Corresponding Author: Joseph.Ready@utsouthwestern.edu. ASSOCIATED CONTENT

Supporting Information. Experimental details, characterization data, and NMR spectra. This material is available free of charge via the Internet at http://pubs.acs.org 
contain a halide on the tyramine side chain, making the use of transition metal-catalyzed reactions challenging. Additionally, a short, flexible synthesis is still needed to provide access to the dictyodendrins and to allow for further SAR studies. Herein, we present a concise synthetic strategy to access previously inaccessible dictyodendrins.

In 2014, we demonstrated that the $t$-butyl ynol ether $\mathbf{8}$ could be prepared using a Sonogashira coupling. Upon heating, the ynol ether converted to aryl ketene $\mathbf{9}$, which could react with diverse nucleophiles to form the corresponding aryl acetic acid derivatives $\mathbf{1 0}$ (Figure 2A). ${ }^{13}$ This method allowed for the rapid introduction of a two-carbon motif on the aromatic ring. However, we also noticed the propensity of aryl ketene 9 to undergo a [2+2]cycloaddition reaction with the aryl ynol ether starting material when nucleophilic trapping was slow. This homo-[2+2]-cycloaddition gave di-arylated cyclobutenone 11. ${ }^{14}$ Upon further heating, cyclobutenone 11 underwent a tandem retro- $4 \pi / 6 \pi$ electrocyclization to generate 1,3-dihydroxyl naphthalene $\mathbf{1 3}$ in high yield. This transformation is reminiscent of the Danheiser benzannulation, in which vinylated cyclobutenones undergo a retro- $4 \pi$ and subsequent $6 \pi$ electrocyclization to generate highly substituted aromatic rings. ${ }^{15}$ More broadly, $6 \pi$ electrocyclization had emerged as an efficient method for forming multisubstituted carbazoles. ${ }^{16}$ The Li group in particular has constructed the central benzene ring of several natural products using $6 \pi$ electrocyclization. ${ }^{17,18}$ Inspired by this cycloaddition/ rearrangement sequence, we hypothesized that a hetero-[2+2]-cycloaddition between indole ynol ether $\mathbf{1 4}$ and 4-anisolyl ynol ether $\mathbf{1 5}$ would allow for a rapid synthesis of the dictyodendrin carbazole core 16 (Figure 2B).

To advance carbazole 16 towards the dictyodendrin F we envisioned replacing the tert-butyl ether with the tyramine side chain to give aminocarbazole 17. A late stage construction of the oxypyrrole ring could involve $N$-acylation followed by an intramolecular oxidative coupling to obtain the desired natural product. This new synthetic route is short but flexible as it also provides access to dictyodendrins $\mathrm{H}$ and $\mathrm{I}$ with an installation of a halogenated tyramine side chain.

Two challenges needed to be addressed to implement this straightforward synthetic route. First, we needed to develop a hetero-[2+2]-cycloaddition reaction between two different aryl ynol ethers with good selectivity. The second challenge would be developing a practical oxidative coupling reaction to afford an oxypyrrole ring. While an oxidative coupling of this type is unprecedented, we reasoned that the electron-rich carbazole $\mathbf{1 7}$ could be coaxed to undergo the desired transformation.

\section{Results and Discussion}

To initiate the synthesis, we first explored the hetero-[2+2]-cycloaddition reaction via a model study between two tert-butyl ynol ethers (8 and 18a) (Table 1). Unfortunately, we observed all four possible cycloaddition products. Changing the equivalents of ynol ether 18a induced a slight improvement of the selectivity towards the desired hetero-dimer $\mathbf{A B}$ (entries 1-3). However, increasing 18a also introduced more undesired hetero-dimer BA and homo-dimer BB. Since the selectivity was not improved by changing the ratio of the starting materials, we next explored the use of different ynol ethers. In particular, we reasoned that 
the use of a thermally stable aryl ynol ether would suppress its ketene formation, which should eliminate two undesired products, BA and BB. With this in mind, we synthesized adamantyl ynol ether $\mathbf{1 8 b}$ (see below). Its cage structure forbids the 1,5-hydride shift to prevent the generation of a bridge-head double bond. As expected, no aryl ketene was generated when adamantyl ynol ether $\mathbf{1 8 b}$ was heated at reflux in toluene for several days, and a quantitative recovery of $\mathbf{1 8 b}$ was possible.

We tested adamantyl ynol ether $\mathbf{1 8 b}$ in the [2+2]-cycloaddition reaction with tert-butyl ynol ether 8. To our delight, a vast improvement for the desired homodimer $\mathbf{A B}$ was observed with no appreciable amount of products $\mathbf{B B}$ and $\mathbf{B A}$. Further improvement in this reaction was achieved by increasing the amount of ynol ether 18b (entries 3-6). A 19:1 selectivity of the hetero- versus homo-cyclization product was obtained when 2.5 equivalents of $\mathbf{1 8 b}$ were used. In this context, the methyl ynol ether would also not undergo the retro-ene reaction to form ketene. However, methyl ynol ethers are much more hydrolytically labile than their bulkier counterparts. Thus, the adamantyl ynol ether appeared to combine stability with the reactivity profile we needed.

Following the preliminary optimization of the hetero-[2+2]-cycloaddition reaction, we next attempted to use this reaction with tert-butyl indolyl ynol $\mathbf{2 0}$ ether and $\mathbf{1 8 b}$ to synthesize dictyodendrins. The adamantyl anisolyl ynol ether $\mathbf{1 8 b}$ was synthesized via a Negishi coupling of adamantoxyethynyl zinc chloride and 4-iodoanisole 22 (Scheme 1). Himbert and Löffler's original protocol for related couplings used $\mathrm{PPh}_{3}$ as the ligand. ${ }^{19}$ In our hands, these conditions resulted in polymerization of the ynol ether. Similarly, in 2014 the Stoltz group disclosed a Negishi coupling between methoxyethynyl zinc chloride and a vinyl iodide; they noted that a xantphos ligand minimized polymerization of the alkyne due to its large bite angle. ${ }^{20,21}$ Following their lead, we evaluated chelating diphosphines in the series $\mathrm{Ph}_{2} \mathrm{P}-\left(\mathrm{CH}_{2}\right)_{\mathrm{n}}-\mathrm{PPh}_{2}$ and found that the yield in the Negishi coupling correlated with the bite angle. Under optimized conditions, 1,6-bis(diphenylphosphine)hexane (dpph) ligand afforded adamantyl anisolyl ynol ether $\mathbf{1 8 b}$ in $80 \%$ yield (Scheme 1A). ${ }^{22}$ In parallel, tertbutyl indolyl ynol ether $\mathbf{2 0}$ was synthesized according to the Sonogashira coupling condition that we reported previously. ${ }^{13}$ Dichloromethane was added as co-solvent to improve the solubility of the starting material $\mathbf{1 9},{ }^{23}$ and a $75 \%$ yield of the benzene sulfonamide (Bs) protected indole $\mathbf{2 0}$ was obtained.

With the desired ynol ethers $\mathbf{2 0}$ and $\mathbf{1 8 b}$ in hand, we turned our attention to the key [2+2]cycloaddition reaction. As we established in the model study, heating indolyl tert-butyl ynol ether 20 to $50{ }^{\circ} \mathrm{C}$ afforded indolyl ketene 21 , which reacted with adamantyl ynol $\mathbf{1 8 b}$. The cycloaddition formed the desired product $\mathbf{2 2}$ as an 11:1 mixture with homo-dimer $\mathbf{2 4}$. As expected there was no ketene generated from adamantyl ynol ether 18b. Interestingly, the protecting group of the indole nitrogen affected the hetero/homo dimer selectivity (22:24; NBs: 11:1; N-Cbz: 7:1; N-Ns: unstable; N-Ts: poor solubility). Moreover, the Bs-protected indole could be synthesized most efficiently among the substrates that we examined. ${ }^{24}$

To our surprise, the desired cyclobutenone 22 spontaneously underwent the retro- $4 \pi / 6 \pi$ electrocyclization to yield the $O$-adamantyl carbazole 23 in $50-60 \%$ yield after $48 \mathrm{~h}$ at $50{ }^{\circ} \mathrm{C}$. In the model study (Table 1), the electrocyclization product was not formed until the 
reaction was heated over $90{ }^{\circ} \mathrm{C}$ for extended times. To take advantage of the unexpected formation of carbazole $\mathbf{2 3}$, we next attempted to introduce the tyramine side chain. Unfortunately, we were unable to displace or remove the adamantyl group successfully. We therefore decided to introduce the tyramine moiety onto the cyclobutenone $\mathbf{2 2}$ instead of at the carbazole stage. This idea was inspired by literature precedent from Turnbull and Moore, wherein they replaced a methoxyl group on a cyclobutenone with an aliphatic amine. ${ }^{15 \mathrm{~d}}$

For cyclobutanone $\mathbf{2 2}$ to serve as a viable synthetic intermediate, we needed to stop the reaction of ynol ethers $\mathbf{1 8 b}$ and $\mathbf{2 0}$ after [2+2]-cycloaddition, but before rearrangement to carbazole 23. In situ ${ }^{1} \mathrm{H}$ NMR was utilized to study the product distribution from this reaction as a function of time (Scheme 1B). ${ }^{25}$ Analysis of this experiment showed a quick consumption of tert-butyl ynol ether $\mathbf{2 0}$ as well as accumulation of the desired cyclobutenone 22 within the first 12 hours. Meanwhile, the formation of the undesired carbazole $\mathbf{2 3}$ was comparatively slow. Therefore, terminating the cycloaddition after 9 hours at $50{ }^{\circ} \mathrm{C}$ allowed us to isolate $56 \%$ cyclobutenone $22,9 \%$ carbazole $23,2.5 \%$ homo-dimer 24, and 20\% unreacted indolyl ynol ether 20 (Scheme 1B). Re-subjection of the unreacted indolyl ynol ether $\mathbf{2 0}$ to the reaction conditions afforded a $68 \%$ total yield of the desired cyclobutenone $\mathbf{2 0}$ and $14 \%$ of undesired carbazole $\mathbf{2 3} .{ }^{26}$

With access to gram quantities of cyclobutenone 22, the substitution reaction was then studied. Besides Turnbull and Moore's work, ${ }^{15 \mathrm{~d}}$ similar substitution reactions have been extensively studied, wherein different nucleophiles were investigated to replace alkoxyl moieties on cyclobutenediones. ${ }^{27}$ Inspired by previous studies, we assumed that $O$ methyltyramine would react with the carbonyl on cyclobutenone 22 to form hemiaminal 25 (Scheme 2). Loss of water would yield the iminium 28. Substitution with water (shown) or loss of adamantyl cation (not shown) should furnish the desired cyclobutenone 29.

Performing the reaction in acetonitrile unfortunately led to a substantial amount of undesired ring-open product 27 (Scheme 2, entry 3). The ring-open product 27 presumably also arose from hemiaminal intermediate $\mathbf{2 6}$ via protonation and fragmentation (Scheme 2, red arrows). The product distribution was inert to changes in temperature, $\mathrm{pH}$, or concentration, but it displayed a noticeable solvent effect. In non-polar solvents (such as toluene, entry 2) or amine solvent (such as $\mathrm{Et}_{3} \mathrm{~N}$, entry 1), the reaction was slow and favored the ring-open product 27. Even if cyclobutenone $\mathbf{2 2}$ was treated with neat tyramine $\mathbf{2 5}$, we failed to obtain a reasonable yield of the desired product $\mathbf{2 9}$, although starting material was consumed (entry 4). In contrast, highly polar solvents accelerated the reaction and preferentially led to the formation of vinylogous amide 29. For example, when DMF was the reaction solvent, full conversion of starting material $\mathbf{2 2}$ indicated a faster reaction rate, and the desired tyraminesubstituted product $\mathbf{2 9}$ was isolated in $71 \%$ yield (entry 5). Finally, DMSO gave the desired product in the highest yield, $79 \%$ (entry 6). Cyclobutenone $\mathbf{2 9}$ proved to be light-sensitive, but it could be handled in amber vials and dark fume hoods.

The next step in the synthesis was the retro- $4 \pi / 6 \pi$ rearrangement. We first tested this rearrangement by heating cyclobutenone 29 at $60{ }^{\circ} \mathrm{C}$ (Scheme 3). A $4 \pi$ electrocyclic ringopening could generate the conjugated ketene intermediate 30; subsequent $6 \pi$ electrocyclization and tautomerization would afford carbazole 33. However, this substrate 
generated only a $20 \%$ yield of desired product $\mathbf{3 3}$ along with numerous unidentified decomposition products. Further study revealed carbazole $\mathbf{3 3}$ was prone to aerobic oxidation and was thermally unstable. We hypothesized that the instability of carbazole $\mathbf{3 3}$ arose from electron-rich heteroaromatic ring system. We therefore reasoned that $\mathrm{N}$-acylation might reduce the electron density of carbazole $\mathbf{3 3}$, thereby generating a more stable intermediate. To test this hypothesis, we acylated carbazole $\mathbf{3 3}$ using the acid chloride $\mathbf{3 1}$ to generate carbazole 35 in $40 \%$ yield. The regioselectivity of this acylation was confirmed using $\mathrm{HMBC}$ and nOe experiments. As expected, the $\mathrm{N}$-acylated carbazole 35 was much more stable under aerobic and thermal conditions than its $\mathrm{N}-\mathrm{H}$ counterpart 33. Given the increased stability of the acylated product, we attempted to avoid isolating the unstable intermediate 33 in order to improve the total yield of the sequence. Thus, cyclobutenone 29 was Nacylated to provide vinylogous imide $\mathbf{3 2}$. Unlike the $\mathrm{N}$-acylation of carbazole $\mathbf{3 3}$, the acylation of cyclobutenone $\mathbf{2 9}$ required a strong base, $\mathrm{NaH}$. Moreover, this acylation was messy, only yielding $53 \%$ of the desired intermediate 32. Even though the subsequent electrocyclization gave the carbazole $\mathbf{3 5}$ in quantitative yield, the total mass balance for these two steps was disappointing due to the difficult $\mathrm{N}$-acylation.

An alternative solution to address the instability of unacylated carbazole $\mathbf{3 3}$ would be to trap it in situ in a one-pot electrocyclization/acylation sequence. All efforts to effect this one-pot procedure were in vain using a traditional acid chloride/base conditions. The starting material 29 quickly decomposed under thermal conditions in the presence of any base. We therefore turned to chemistry previously developed in our lab using tert-butyl ynol ethers as acylating reagents. Heating ynol ethers generates aryl ketenes under neutral conditions. Hence, we carried out a one-pot electrocyclization-acylation reaction with cyclobutenone $\mathbf{2 9}$ and 4-anisolyl tert-butyl ynol ether 18a as the acylating reagent (Figure 3). We were pleased to see a $27 \%$ yield of the acylated carbazole 35 was obtained with $60 \%$ starting material 29 recovered at $50{ }^{\circ} \mathrm{C}(40 \%$ conversion, entry 1$)$. The mass recovery of this reaction was encouraging, but the low conversion left room for improvement.

Initial efforts to optimize this retro- $4 \pi / 6 \pi$-cyclization-acylation cascade reaction focused on increasing the reaction temperature to achieve a high conversion. A slight increase in temperature to $60^{\circ} \mathrm{C}$ led to a small improvement in yield (38\%, Figure 3, entry 2). Unfortunately, the unacylated carbazole $\mathbf{3 3}$ was also observed, as well as its decomposition products at this temperature. Increasing the reaction temperature further to $70{ }^{\circ} \mathrm{C}$ only gave a $47 \%$ yield at $100 \%$ conversion (entry 3 ). Again, we used in situ ${ }^{1} \mathrm{H}$ NMR to study this reaction. Unacylated carbazole $\mathbf{3 3}$ was present throughout the reaction time course, indicating that the acylation actually occurred on carbazole 33, not on the cyclobutenone 29. Moreover we found that the tert-butyl ynol ether 18a was consumed in the first 4 hours at $60{ }^{\circ} \mathrm{C}$. These observations indicated that there was insufficient ketene 36 being formed in the later stages of the reaction to trap newly formed carbazole 33. Accordingly, we next tried a batchwise addition of ynol ether 18a to introduce aryl ketene $\mathbf{3 6}$ slowly, but this attempt to increase the yield had a limited success. ${ }^{28}$ Batchwise addition of ynol 18a likely sustained low levels of ketene $\mathbf{3 6}$ for a longer time relative to our original reaction conditions, as intended. However, this protocol also increased the chance of introducing oxygen and 
diluted the reaction medium, both of which were detrimental. We therefore considered alternative approaches to generate aryl ketene $\mathbf{3 6}$ more slowly.

We reasoned that the kinetics of ketene generation could be modulated by changing the tertbutyl group of the ynol ether, which could allow for extending the release time of aryl ketene $\mathbf{3 6}$ during the reaction. Thus, with slower generation, aryl ketene $\mathbf{3 6}$ could be available to acylate carbazole 33 throughout the entire 12 hour reaction without the need for a slow addition protocol. To identify an appropriate ketene precursor and to quantify the rate of ketene generation, we studied the acylation of aniline (Figure 4A). Tracking these reactions by in situ ${ }^{1} \mathrm{H} \mathrm{NMR}$, we could obtain the rate of ketene generation from various anisolyl ynol ethers at $70{ }^{\circ} \mathrm{C} .{ }^{25}$ The kinetic traces shown in Figure 4B indicated that ketene generation was $1^{\text {st }}$ order in ynol ether 18, as expected. The 3-pentyl anisolyl ynol ether 18c emerged as an ideal aryl ketene precursor. Specifically, 3-pentyl ynol ether 18c generated ketene 36 approximately one-third as quickly as tert-butyl ynol ether 18a, leading to ketene generation over a longer time period. Ultimately, utilizing 3-pentyl anisolyl ynol ether 18c as the acylating reagent in the retro- $4 \pi / 6 \pi$-cyclization-acylation cascade sequence, we obtained the desired $\mathrm{N}$-acylated carbazole product $\mathbf{3 5}$ in $91 \%$ isolated yield (Figure $4 \mathrm{C}$ ).

With the acylated carbazole intermediate $\mathbf{3 5}$ in hand, we turned our attention to the oxidative coupling reaction to form the desired oxypyrrole ring. Although not totally unprecedented, there are limited reports of analogous intramolecular oxidative couplings between benzyl and aryl carbons. The Baran group demonstrated a series of iron- and copper-mediated intermolecular oxidative couplings between enolates and indoles or pyrroles, ${ }^{29}$ but this was limited to electron rich heterocycles as the oxidative coupling partner. More recently, the $\mathrm{Ma}$ group used a di-radical intermediate to couple the $\mathrm{C}_{3}$ of an indole and the a-position of an aryl acetamide in their synthesis of communisin $\mathrm{F}^{30}$ However, an electron withdrawing group on the aryl acetamide was required to achieve a good yield for this reaction.

Subjecting substrate 35 to Ma's conditions, $\mathrm{I}_{2}$ and LiHMDS, only resulted in para-iodination of the phenol. ${ }^{31}$

Fortuitously, we found that the benzenesulfonate protecting group could act as the oxidant in the oxidative cyclization of amide $\mathbf{3 5}$ (Scheme 4). In detail, when LiHMDS was added to substrate 35 at $-78{ }^{\circ} \mathrm{C}$ and warmed to room temperature, the reaction solution changed from colorless to dark green. The reaction mixture subsequently evolved to a red-brown solution from which we isolated the desired oxidative coupling product 43 . To our surprise, the benzenesulfonate group was lost during the reaction. We first excluded air as the oxidant in the reaction by executing a strict degassing protocol. The dramatic color change still occurred, indicating the formation of the large conjugated system in the dictyodendrins' scaffold. Quenching the dark green intermediate $\mathbf{4 1}$ with a degassed aqueous solution of $\mathrm{NaHCO}_{3}$ afforded a colorless cyclized product $\mathbf{4 2}$ at a phenolic oxidation state in $62 \%$ yield. ${ }^{32}$ The structure of cyclized product $\mathbf{4 2}$ was confirmed through 1- and 2-dimensional NMR. ${ }^{33}$ Intermediate $\mathbf{4 2}$ slowly converted into the red-brown quinone $\mathbf{4 3}$ in the presence of $\mathrm{Et}_{3} \mathrm{~N}$ under aerobic conditions. However, injecting a trace amount of air to the dark green anionic intermediate $\mathbf{4 1}$ immediately gave the red-brown quinone product $\mathbf{4 3}$ in $67 \%$ yield. 
The rapid aerobic oxidation of intermediate $\mathbf{4 1}$ excludes trace oxygen as the oxidant for the first C-C bond-forming step in this sequence $(\mathbf{3 5} \rightarrow \mathbf{4 1})$. In particular, oxidation of $\mathbf{4 1}$ is faster than the oxidative cyclization of $\mathbf{3 5}$. For this reason, had trace levels of oxygen been present in the reaction mixture, 4-electron oxidation to 35 to quinone $\mathbf{4 3}$ would have been observed. In practice, we were able to isolate phenol $\mathbf{4 2}$, the product of a 2 electron oxidative cyclization. The oxidative cyclization could use the S-O bond of the benezulfonate as the oxidizing equivalent as illustrated in Scheme 4. Following deprotonation, loss of sulfinate ion $\mathrm{PhSO}_{2}^{-}$from carbazole 35 could generate an azaquinone-type intermediate 39. 5-Exo cyclization of the enolate could form the final C-C bond of the natural product, and tautomerization and protonation could yield the lactam 42. ${ }^{34,35}$ Our final optimized conditions for the oxidative coupling reaction used $\mathrm{PhI}(\mathrm{OAc})_{2}$ as a co-oxidant instead of air to oxidize diphenolic intermediate $\mathbf{4 1}$ into the desired quinone $\mathbf{4 3}$, and it gave a $92 \%$ yield of the desired product $\mathbf{4 3}$ (Scheme 5). This protected form of dictyodendrin $\mathrm{F}$ was previously prepared by the Davies group. ${ }^{10}$ Following their prescription, global deprotection gave dictyodendrin $\mathrm{F}$ in $63 \%$ yield. In summary, we synthesized dictyodendrin $\mathrm{F}$ with the longest linear sequence of 6 operations from indole $\mathbf{1 9}$ and a 20.2\% total yield.

With this highly efficient synthetic strategy developed, we were also able to synthesize dictyodendrins $\mathrm{H}$ and $\mathrm{I}$ using the same synthetic sequence and only changing tyramine to a halogenated tyramine (Scheme 6). Unlike dictyodendrin F, dictyodendrins H and I contain a halogen atom on the tyramine side chain, making transition metal catalyzed cross-couplings or $\mathrm{C}-\mathrm{H}$ activation strategies challenging. In addition, a late stage halogenation could also be difficult given the large number of electron-rich aromatic rings. By contrast, our approach avoids these problems by using the desired halogenated tyramines to replace the adamantoxyl group on the cyclobutenone. In detail, halogenated $O$-methyl tyramines 44 (X $=\mathrm{Br})$ and $\mathbf{4 5}(\mathrm{X}=\mathrm{I})^{36}$ were used to replace the adamantoxyl group on cyclobutenone 22 to obtain the tyramine substituted cyclobutenones 46 and 47 . The subsequent retro- $4 \pi / 6 \pi$ cyclization-acylation cascade reaction afforded the carbazole intermediates 48 and 49 using 3-pentyl anisolyl ynol ether $\mathbf{1 8 c}$ as the acylating reagent. Finally, oxidative coupling and global deprotection gave dictyodendrins $\mathrm{H}$ and I. The ${ }^{1} \mathrm{H}$ NMR spectra for the synthetic materials matched the reported data for the natural products. The isolation group was unable to obtain complete ${ }^{13} \mathrm{C}$ NMR data sets, but our synthetic material generated spectra that were consistent with the limited data that is available. ${ }^{37}$ During the synthesis, we found that the halide on the side chain caused some instability during the cascade reaction (more lightsensitive) as well as during the oxidative coupling reaction. In conclusion, we report the first total synthesis of dictyodendrins H (6) and I (7) in six steps with an $11.9 \%$ and $11 \%$ total yield, respectively.

The cytotoxicity of dictyodendrins F, H, and I was evaluated against three non-small cell lung cancer cell lines (H157, H2073, H2122) and a colorectal cancer cell line (HCT116). ${ }^{33}$ Interestingly, with the increasing size of the tyramine side chain from dictyodendrin F to I, we observed increasing, albeit modest cytotoxicity of the natural products against cancer cells. For example, the $\mathrm{IC}_{50}$ values against HCT116 decreased from dictyodendrin $\mathrm{F}$ (26.9 $\mu \mathrm{M})$ to dictyodendrin $\mathrm{H}(13 \mu \mathrm{M})$ and dictyodendrin $\mathrm{I}(8 \mu \mathrm{M})$ (Figure 5). The concise 
syntheses described here should provide a route to access multiple derivatives of the dicyodendrins to optimize their activity and identify relevant biological targets.

\section{Supplementary Material}

Refer to Web version on PubMed Central for supplementary material.

\section{ACKNOWLEDGMENT}

We appreciate helpful suggestions from Prof. George O'Doherty (Northeastern University) regarding the mechanism of oxidative cyclization. We thank Dr. Lin Feng (UT Southwestern) for help with in situ NMR experiments, Dr. Shi Heping (UT Southwestern) for help with mass spectrometry. We thank Dr. Bruce Posner (UT Southwestern) Chensu Wang (UT Southwestern) for help measuring cytotoxicity. We thank Prof. Robert Capon (The University of Queensland) providing NMR spectra of isolated dictyodendrins F and I for comparison. Sarah Winterton and Aaron Coffin helped edit the manuscript. Funding was provided by Sarah and Frank McKnight Fellowship for Biochemical Research, NIGMS (R01 GM102403), and the Welch Foundation (I-1612).

\section{REFERENCES}

(1). Warabi K, Matsunaga S, van Soest RWM, Fusetani N. J. Org. Chem. 2003; 68:2765-2770. [PubMed: 12662050]

(2). Parkinson EK. Ann. Med. 2003; 35:466-475. [PubMed: 14649329]

(3). Zhang H, Conte MM, Khalil Z, Huang X-C, Capon RJ. RSC Adv. 2012; 2:4209-4214.

(4). (a) John V, Beck JP, Bienkowski MJ, Sinha S, Heinrikson RL. J. Med. Chem. 2003; 46:46254630. [PubMed: 14561080] (b) Baxter, EW.; Reitz, AB. Annual Reports in Medicinal Chemistry. Doherty, AM.; Bock, MG.; Desai, MC.; Overington, J.; Plattner, JJ.; Stamford, AS.; Wustrow, D.; Hannah, Y., editors. Vol. 40. Academic Press; 2005. p. 35-48.(c) Varghese J. Curr. Top. Med. Chem. 2006; 6:569-578. [PubMed: 16712492]

(5). Ayats C, Soley R, Albericio F, Alvarez M. Org. Biomol. Chem. 2009; 7:860-862. [PubMed: 19225666]

(6). Synthesis of dictyodendrins B, C, E, and F: Fürstner A, Domostoj MM, Scheiper B. J. Chem. Am. Soc. 2005; 127:11620-11621. Fürstner A, Domostoj MM, Scheiper B. J. Chem. Am. Soc. 2006; 128:8087-8094. Buchgraber P, Domostoj MM, Scheiper B, Wirtz C, Mynott R, Rust J, Fürstner A. Tetrahedron. 2009; 65:6519-6534.

(7). (a) Hirao S, Sugiyama Y, Iwao M, Ishibashi F. Biosci. Biotechnol. Biochem. 2009; 73:1764-1772. [PubMed: 19661693] (b) Hirao S, Yoshinaga Y, Iwao M, Ishibashi F. Tetrahedron Lett. 2010; 51:533-536.

(8). Synthesis of dictyodendrins A-E: Okano K, Fujiwara H, Noji T, Fukuyama T, Tokuyama H. Angew. Chem. Int. Ed. 2010; 49:5925-5929. Tokuyama H, Okano K, Fujiwara H, Noji T, Fukuyama T. Chem. - Asian J. 2011; 6:560-572. [PubMed: 20936666]

(9). Synthesis of dictyodendrin B: Pitts AK, O’Hara F, Snell RH, Gaunt MJ. Angew. Chem. Int. Ed. 2015; 54:5451-5455.

(10). Synthesis of dictyodendrins A and F: Yamaguchi AD, Chepiga KM, Yamaguchi J, Itami K, Davies HML. J. Chem. Am. Soc. 2015; 137:644-647.

(11). Synthesis of dictyodendrins B, C, and E: Liang J, Hu W, Tao P, Jia Y. J. Org. Chem. 2013; 78:5810-5815. [PubMed: 23701029] Tao P, Liang J, Jia Y. Eur. J. Org. Chem. 2014; 2014:57355748.

(12). For selected reviews on C-H functionalization in natural product synthesis: McMurray L, O'Hara F, Gaunt MJ. Chem. Soc. Rev. 2011; 40:1885-1898. [PubMed: 21390391] Gutekunst WR, Baran PS. Chem. Soc. Rev. 2011; 40:1976-1991. [PubMed: 21298176] Chen DYK, Youn SW. Chem. Eur. J. 2012; 18:9452-9474. [PubMed: 22736530] Yamaguchi J, Yamaguchi AD, Itami K. Angew. Chem. Int. Ed. 2012; 51:8960-9009.

(13). Zhang W, Ready JM. Angew. Chem. Int. Ed. 2014; 53:8980-8984. 
(14). Kohnen AL, Mak XY, Lam TY, Dunetz JR, Danheiser RL. Tetrahedron. 2006; 62:3815-3822. [PubMed: 21394235]

(15). For selected Danheiser benzannulation reactions, see: Danheiser RL, Gee SK. J. Org. Chem. 1984; 49:1672-1674. Xu SL, Moore HW. J. Org. Chem. 1989; 54:4024-4026. Danheiser RL, Brisbois RG, Kowalczyk JJ, Miller RF. J. Chem. Am. Soc. 1990; 112:3093-3100. Turnbull P, Moore HW. J. Org. Chem. 1995; 60:644-649. Dudley GB, Takaki KS, Cha DD, Danheiser RL. Org. Lett. 2000; 2:3407-3410. [PubMed: 11029223] Austin WF, Zhang Y, Danheiser RL. Org. Lett. 2005; 7:3905-3908. [PubMed: 16119928] Mak XY, Crombie AL, Danheiser RL. J. Org. Chem. 2011; 76:1852-1873. [PubMed: 21322545] Lam TY, Wang Y-P, Danheiser RL. J. Org. Chem. 2013; 78:9396-9414. [PubMed: 23952525] Willumstad TP, Haze O, Mak XY, Lam TY, Wang Y-P, Danheiser RL. J. Org. Chem. 2013; 78:11450-11469. [PubMed: 24116731] Bai Y, Yin J, Liu Z, Zhu G. J. Org. Chem. 2015; 80:10226-10233. [PubMed: 26389568]

(16). Formation of carbazoles using $6 \pi$ electrocyclization, see: Bian M, Wang Z, Xiong X, Sun Y, Matera C, Nicolaou KC, Li A. J. Chem. Am. Soc. 2012; 134:8078-8081. Meng Z, Yu H, Li L, Tao W, Chen H, Wan M, Yang P, Edmonds DJ, Zhong J, Li A. Nat. Commun. 2015; 6:6096. [PubMed: 25648883]

(17). (a) Lu Z, Li Y, Deng J, Li A. Nat. Chem. 2013; 5:679-684. [PubMed: 23881499] (b) Xiong X, Li Y, Lu Z, Wan M, Deng J, Wu S, Shao H, Li A. Chem. Commun. 2014; 50:5294-5297.(c) Li J, Yang P, Yao M, Deng J, Li A. J. Chem. Am. Soc. 2014; 136:16477-16480.(d) Yang M, Li J, Li A. Nat. Commun. 2015; 6:6445. [PubMed: 25759087] (e) Yang M, Yang X, Sun H, Li A. Angew. Chem. Int. Ed. 2016; 55:2851-2855.(f) Yang P, Yao M, Li J, Li Y, Li A. Angew. Chem. Int. Ed. 2016; 55:6964-6968.

(18). Formation of multisubstituted arenes, see also: Anderson EA, Alexanian EJ, Sorensen EJ. Angew. Chem. Int. Ed. 2004; 43:1998-2001. Ohmori K, Mori K, Ishikawa Y, Tsuruta H, Kuwahara S, Harada N, Suzuki K. Angew. Chem. Int. Ed. 2004; 43:3167-3171. Greshock TJ, Funk RL. Org. Lett. 2006; 8:2643-2645. [PubMed: 16737334] Sloman DL, Mitasev B, Scully SS, Beutler JA, Porco JA. Angew. Chem. Int. Ed. 2011; 50:2511-2515.

(19). Löffler A, Himbert G. Synthesis. 1992; 1992:495-498.

(20). Gordon JR, Nelson HM, Virgil SC, Stoltz BM. J. Org. Chem. 2014; 79:9740-9747. [PubMed: 25244187]

(21). van Leeuwen PWNM, Zuideveld MA, Swennenhuis BHG, Freixa Z, Kamer PCJ, Goubitz K, Fraanje J, Lutz M, Spek AL. J. Chem. Am. Soc. 2003; 125:5523-5539. (b) For review, see: van Leeuwen PWNM, Kamer PCJ, Reek JNH, Dierkes P. Chem. Rev. 2000; 100:2741-2770. [PubMed: 11749304]

(22). (a) dpp-hexane is a poor ligand for palladium-catalyzed $\mathrm{CO} / \mathrm{C}_{2} \mathrm{H}_{4}$ copolymerization. See: Leeuwen, P. W. N. M. v.; Freixa, Z. Modern Carbonylation Methods. 2008:10.Wiley-VCH Verlag $\mathrm{GmbH} \& \mathrm{Co} . \mathrm{KGaA}$ (b) For bite angle of $\mathrm{Pd}\left[\mathrm{PH}_{2}(\mathrm{CH} 2)_{6} \mathrm{PH}_{2}\right]$, see: van Zeist W-J, Visser R, Bickelhaupt FM. Chem. Eur. J. 2009; 15:6112-6115. [PubMed: 19462388]

(23). Commercially available from Chendu Aofan Pharm-tech Co., Ltd (TEL 86-28-85655382) or available from a 1-pot iodination-sulfonylation of the corresponding indole. See supporting information for details.

(24). N-Cbz gave $84 \%$ yield of impure material in the coupling reaction; N-Ns decomposed during coupling reaction; $\mathrm{N}-\mathrm{Ts}$ had poor solubility for coupling reaction and gave $21 \%$ yield.

(25). ${ }^{1} \mathrm{H}$ NMR key parameters: $\mathrm{nt}=32, \mathrm{~d} 1=4$. The graph in Scheme $1 \mathrm{~B}$ was generating by assuming $[\mathbf{2 0}] \%+[\mathbf{2 2}] \%+[\mathbf{2 3}] \%=100 \%$. No other products were observed in the ${ }^{1} \mathrm{H}$ NMR spectra. The hetero/homo-dimer selectivity did not change over the course of the reaction.

(26). The starting material was reused once.

(27). (a) Schmidt AH, Debo M, Wehner B. Synthesis. 1990; 1990:237-242.(b) Sejwal P, Han Y, Shah A, Luk Y-Y. Org. Lett. 2007; 9:4897-4900. [PubMed: 17929938] (c) Li J, Han Y, Freedman TB, Zhu S, Kerwood DJ, Luk Y-Y. Tetrahedron Lett. 2008; 49:2128-2131.

(28). We added 2.5 equivalents of the ynol ether every 4 hours. Batchwise addition gave $42 \%$ of $\mathbf{3 7}$ at $60{ }^{\circ} \mathrm{C}$ compared to $38 \%$ yield when all reagents were combined at the beginning of the reaction.

(29). (a) Richter JM, Whitefield BW, Maimone TJ, Lin DW, Castroviejo MP, Baran PS. J. Chem. Am. Soc. 2007; 129:12857-12869.(b) DeMartino MP, Chen K, Baran PS. J. Chem. Am. Soc. 2008; 130:11546-11560. 
(30). (a) Zuo Z, Xie W, Ma D. J. Chem. Am. Soc. 2010; 132:13226-13228.(b) Zi W, Zuo Z, Ma D. Acc. Chem. Res. 2015; 48:702-711. [PubMed: 25667972]

(31). The iodinated product was the only product we isolated after the reaction.

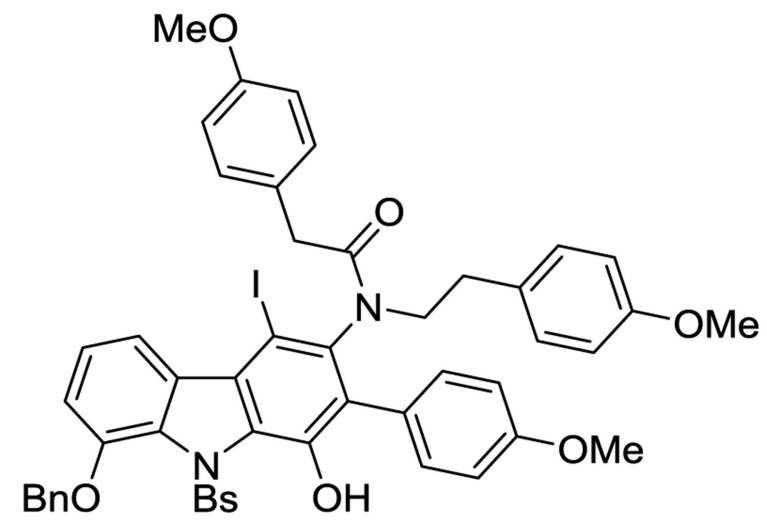

(32). 41 could exist as a di-anion or one of several mono-anions.

(33). See supporting information for details.

(34). For benzenesulfonate acting as an oxidant in the Shapiro reaction, see: Adlington RM, Barrett AGM. Acc. Chem. Res. 1983; 16:55-59.

(35). An alternative mechanism involves migration of the benzenesulfonate from the indole nitrogen to the phenolate anion to form an $\mathrm{ArOSO}_{2} \mathrm{Ph}$ intermediate. Enolate addition to the aromatic ring with loss of $\mathrm{PhSO}_{2}{ }^{-}$and tautomerization would form carbazole 41.

(36). Wing-Wah S. Tetrahedron Lett. 1993; 34:6223-6224.

(37). HSQC and HMBC were employed to assign carbons of dictyodendrins $\mathrm{H}$ and $\mathrm{I}$ by the isolation group. The quantity of natural products was not enough for direct a ${ }^{13} \mathrm{C}$ NMR experiment. See Ref 3. 
<smiles></smiles>

dictyodendrin A (1)

dictyodendrin B (2)

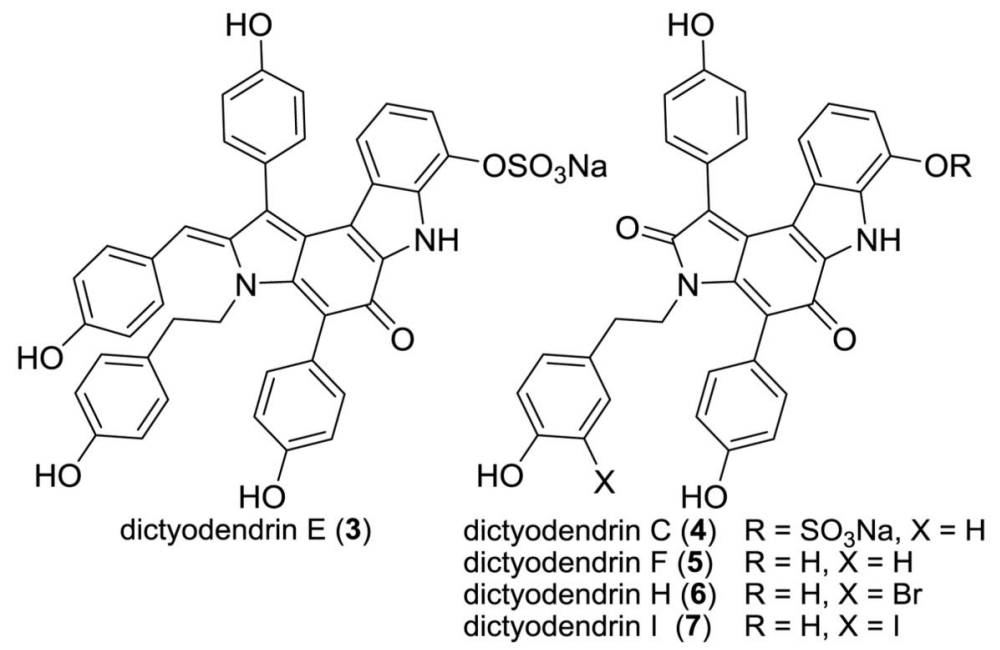

Synthetic Steps (L.L.S)

\begin{tabular}{|c|c|c|c|c|c|c|c|c|}
\hline Dictyodendrins & A & B & $\mathrm{C}$ & $\mathrm{D}$ & $E$ & $\mathrm{~F}$ & $\mathrm{H}$ & 1 \\
\hline Furstner & & 13 & 10 & & 13 & 9 & & Biological activity \\
\hline Ishibashi & & 18 & & & & & & dictyodendrin A-E: \\
\hline Tokuyama & 21 & 21 & 21 & 21 & 22 & & & telomerase inhibitor \\
\hline Jia & & 9 & & & 11 & & & dictyodendrin F-J: \\
\hline Davies & 12 & & & & & 10 & & BACE1 inhibitor \\
\hline Guant & & 13 & & & & & & \\
\hline this work & & & & & & 6 & 6 & 6 \\
\hline
\end{tabular}

Figure 1.

The dictyodendrin family of marine alkaloids and previous synthetic reports of dictyodendrins. 


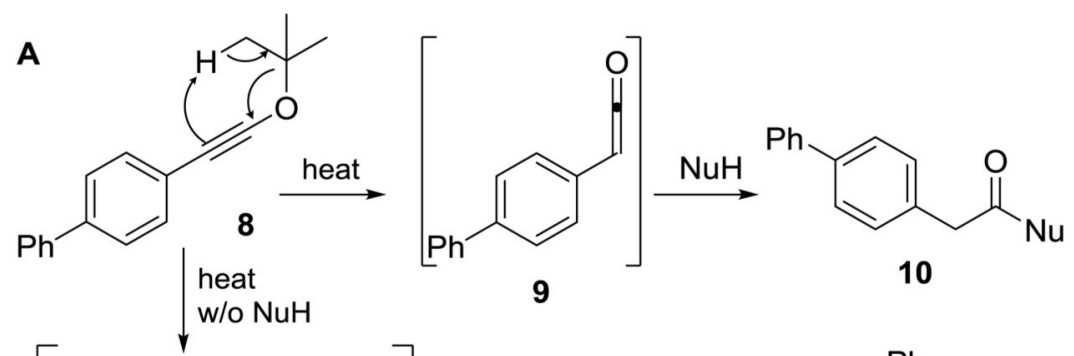

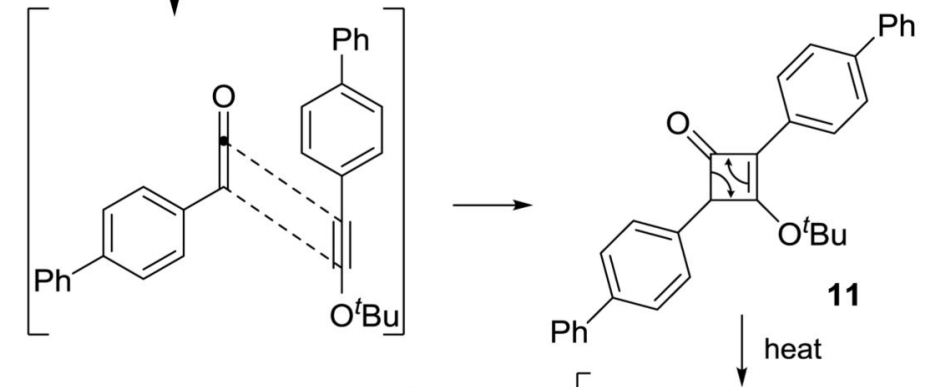
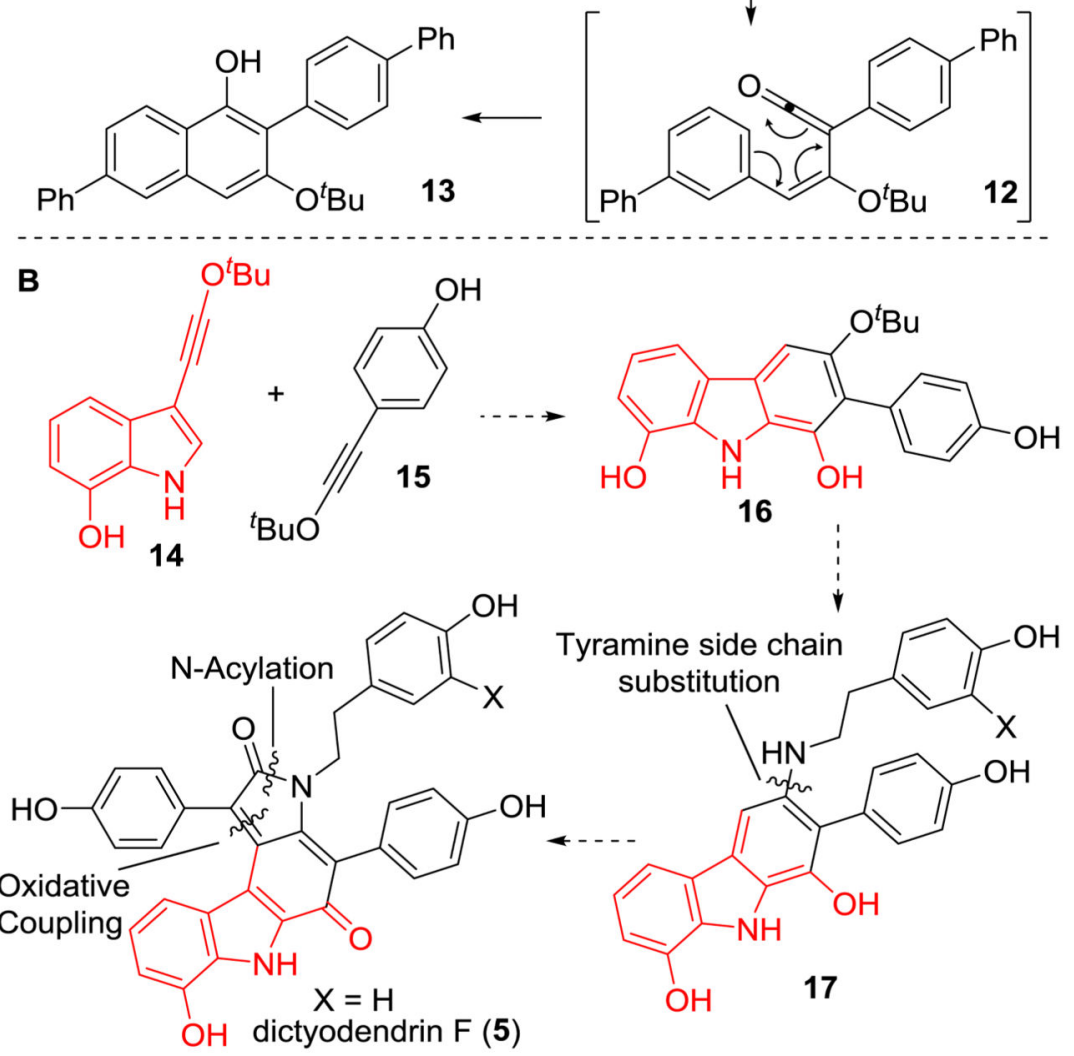

Figure 2.

(A) The discovery of homo-[2+2] cycloaddition of aryl ynol ethers, followed by a rearrangement to naphthol 13. (B) The hetero-[2+2]-cycloaddition of aryl ynol ethers in the synthesis of dictyodendrins. 


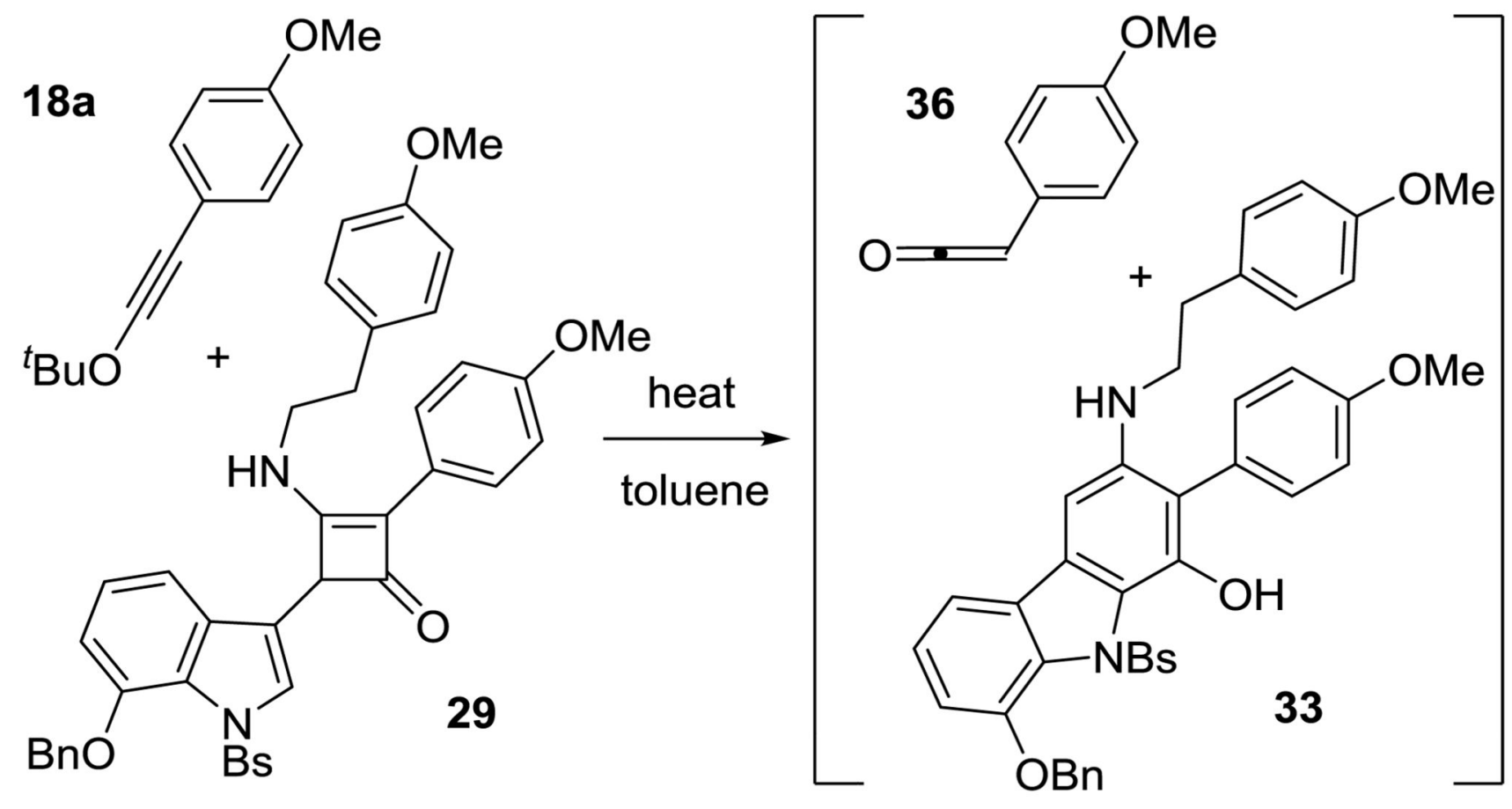

Conditions $^{a}$

\begin{tabular}{|c|c|c|c|}
\hline Entry & Temp. & Product & Conv. \\
\hline 1 & $50^{\circ} \mathrm{C}$ & $27 \%$ & $40 \%$ \\
\hline 2 & $60^{\circ} \mathrm{C}$ & $38 \%$ & $60 \%$ \\
\hline 3 & $70^{\circ} \mathrm{C}$ & $47 \%$ & $100 \%$ \\
\hline
\end{tabular}

Figure 3.

The retro- $4 \pi / 67 \pi$-electrocyclization-acylation cascade reaction. 

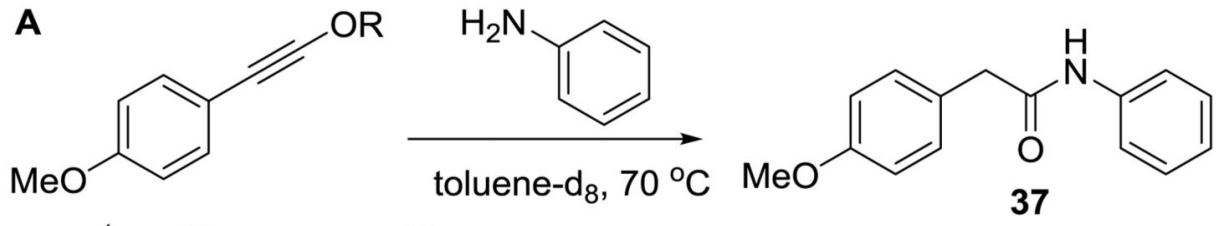

$\mathrm{R}={ }^{t} \mathrm{Bu}$ (18a), 3-Pent (18c)
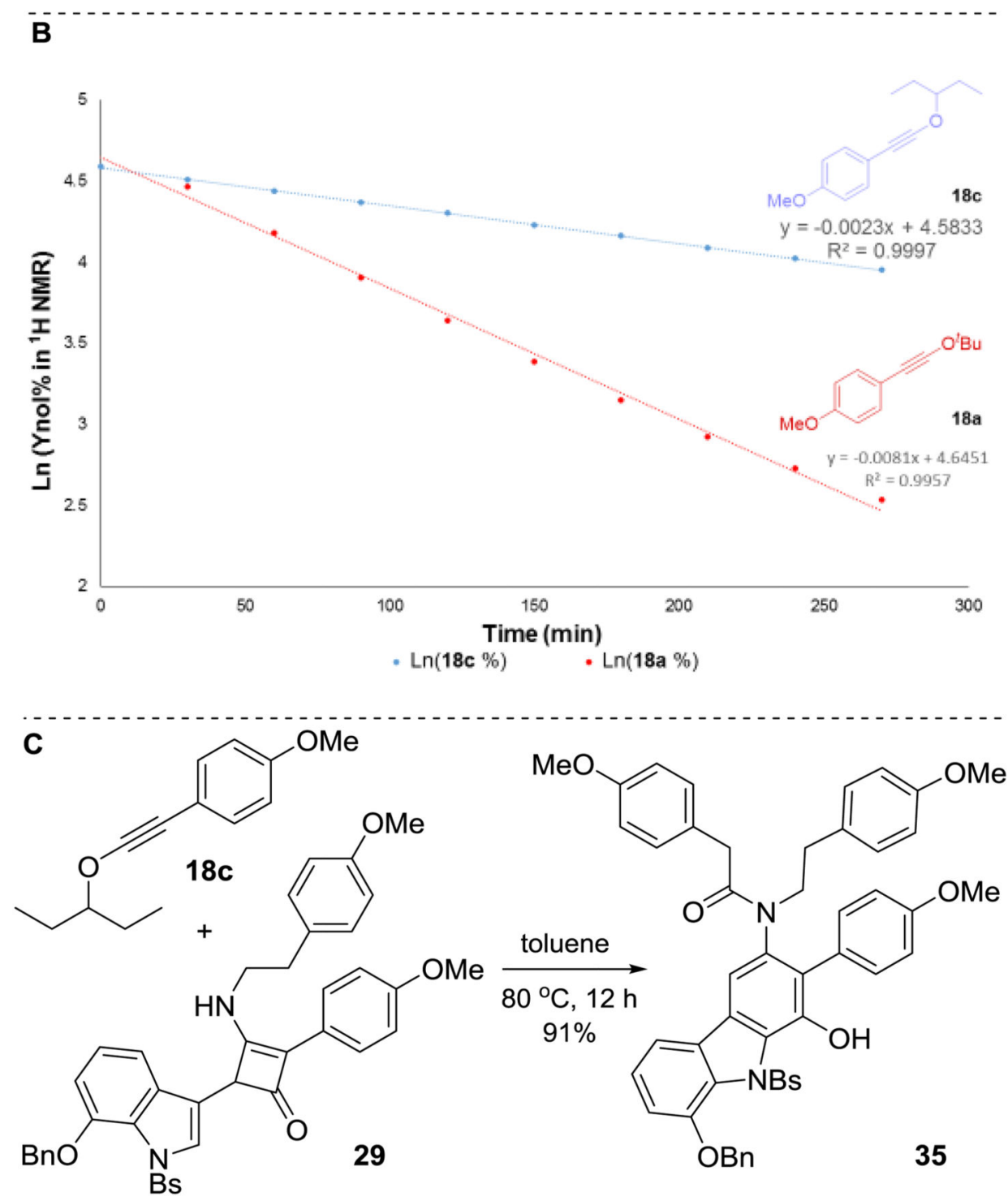

Figure 4.

(A) Acylation of aniline using different anisolyl ynol ethers. (B) Reaction rate comparison between $18 \mathbf{a}$ and $18 \mathrm{c}$ based on in situ ${ }^{1} \mathrm{H}$ NMR analysis. The slopes of the best-fit lines indicate $\mathrm{k}_{18 \mathrm{a}} / \mathrm{k}_{18 \mathrm{c}}=3.5$. (C) The 3-pentyl ynol ether afforded an excellent yield of the retro- $4 \pi / 6 \pi$-electrocyclization-acylation cascade reaction. 


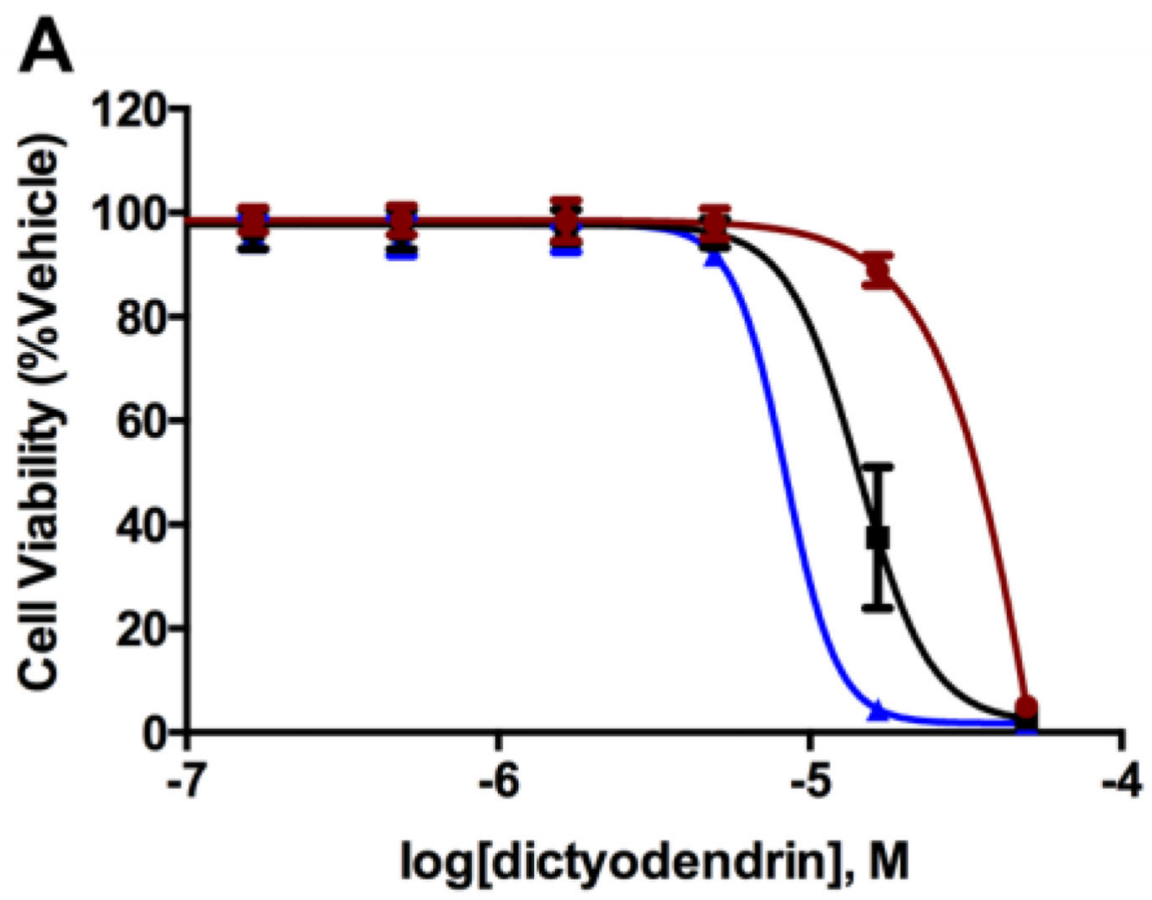

$\rightarrow$ dictyodendrin $\mathrm{F}$

$\rightarrow$ dictyodendrin $\mathrm{H}$

$\mp$ dictyodendrin I

log[dictyodendrin], M

B

\begin{tabular}{lcccc}
\hline & HCT116 & H157 & H2073 & H2122 \\
\hline dictyodendrin F & 26.98 & 14.76 & $>50$ & $>50$ \\
dictyodendrin H & 13.00 & 9.57 & 38.54 & 28.14 \\
dictyodendrin I & 8.78 & 6.39 & 35.39 & 20.22 \\
\hline
\end{tabular}

Figure 5.

(A) Cytotoxicity of dictyodendrins against colon cancer cell line HCT116. (B) The $\mathrm{IC}_{50}$ values of dictyodendrins $(\mu \mathrm{M})$ against cancer cell lines. 


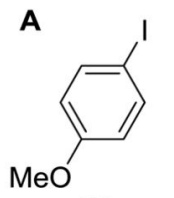

22

a. $\operatorname{Pd}(\mathrm{OAc})_{2}, \mathrm{dpph}$<smiles>COC#Cc1ccc(OC)cc1</smiles>
$80 \%$<smiles></smiles>
b. $\mathrm{Pd}(\mathrm{OAc})_{2}, \mathrm{TFP}, \mathrm{Cul}$ $19\left(\mathrm{Bs}=\mathrm{PhSO}_{2}-\right)$<smiles>C#Cc1c(C)[nH]c2c(OCc3ccccc3)cccc12</smiles>

20

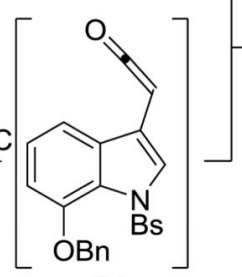

21

$50^{\circ} \mathrm{C}$

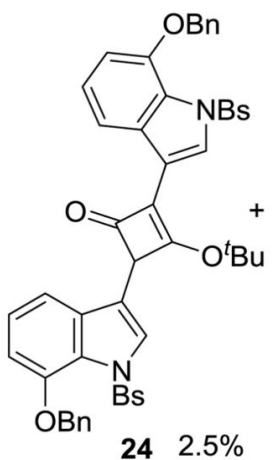<smiles></smiles>

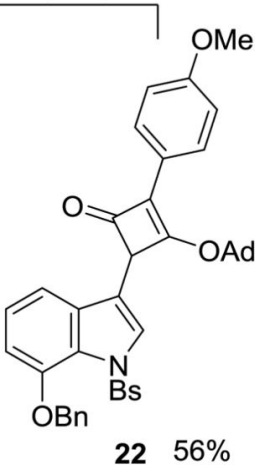

homo-dimer rearranged hetero-dimer hetero-dimer

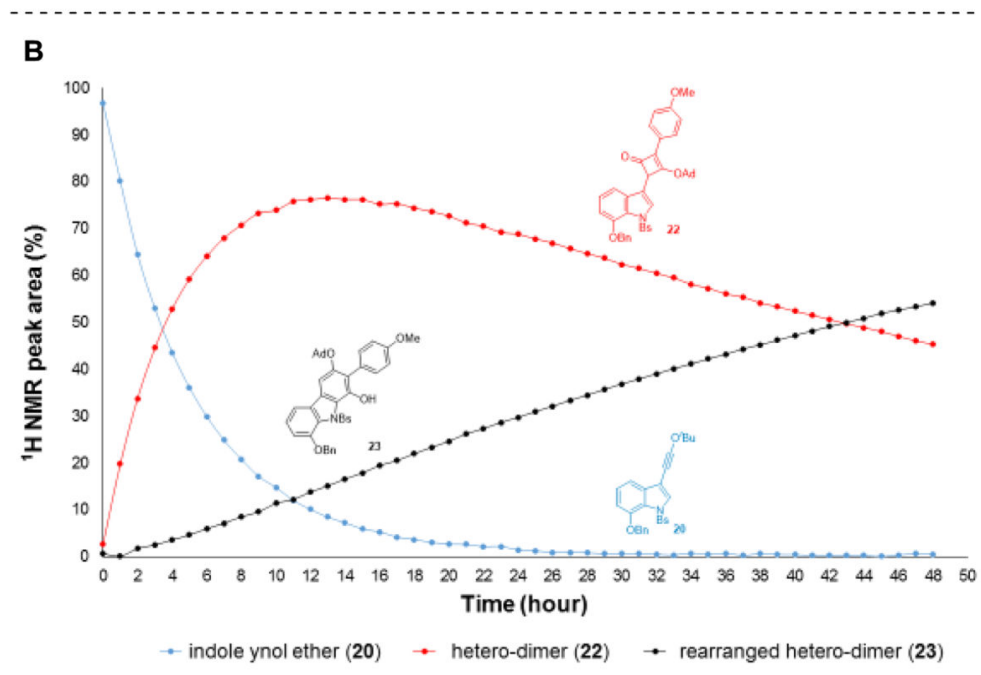

Scheme 1. Synthesis of the hetero-[2+2]-cycloaddition product ${ }^{a}$

${ }^{a}$ Reagents and conditions: (a) 1,6-bis(diphenylphosphine)hexane (10 mol\%), $\mathrm{Pd}(\mathrm{OAc})_{2}(5$ mol\%), adamantoxylethynyl zinc chloride (1.5 equiv), THF, $23{ }^{\circ} \mathrm{C}, 4 \mathrm{~h}, 80 \%$; (b) $\mathrm{Pd}(\mathrm{OAc})_{2}$ (10 mol\%), tri(2-furyl)phosphine (20 mol\%), Cul (15 mol\%), $t$-butoxylacetylene (10 equiv), diiospropylamine/DCM (1:1), $23{ }^{\circ} \mathrm{C}, 12 \mathrm{~h}, 75 \%$; (c) toluene, $50{ }^{\circ} \mathrm{C}, 9 \mathrm{~h}, 56 \% 22(68 \%$ b.r.s.m.). 

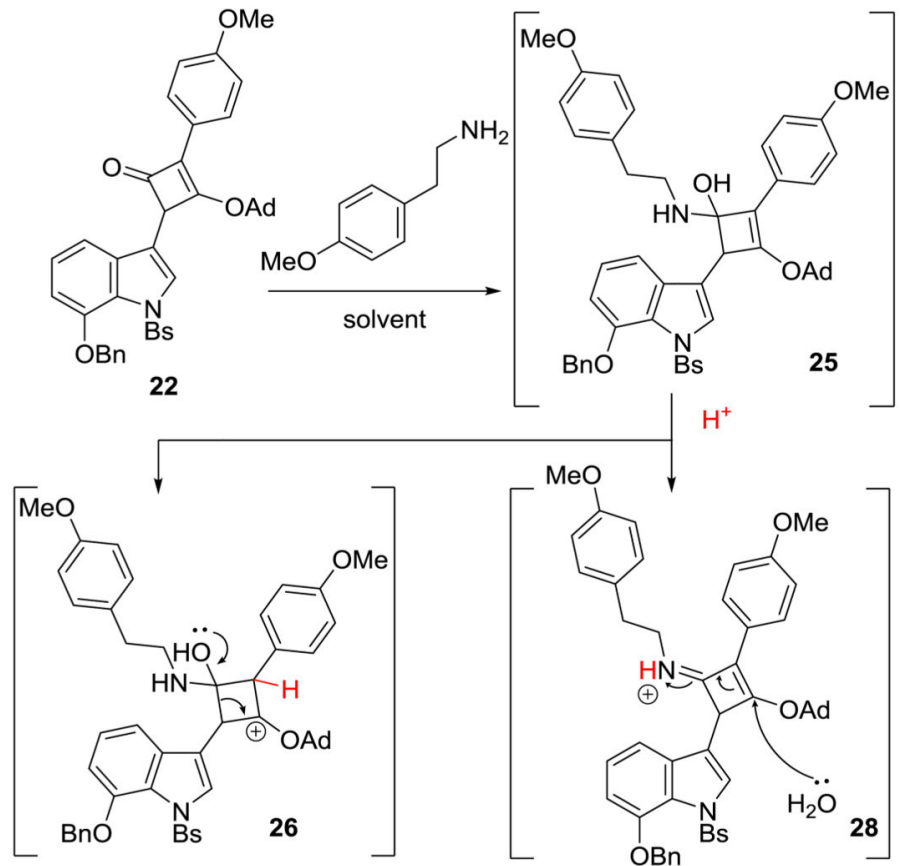

$-\mathrm{H}^{+}$
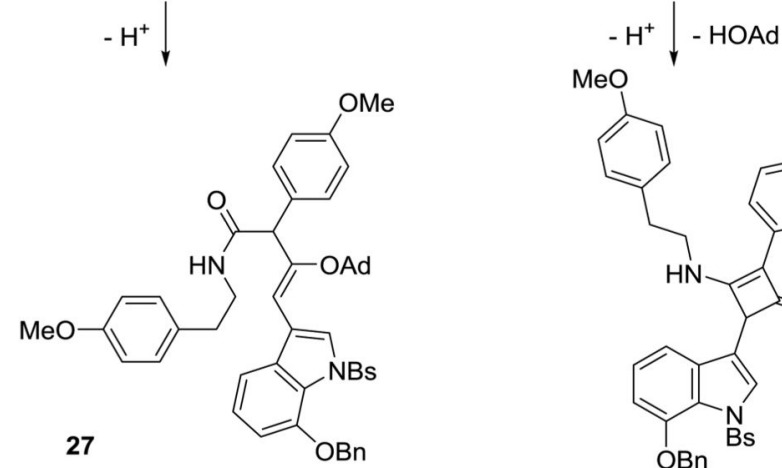

$\mathrm{Bn}$

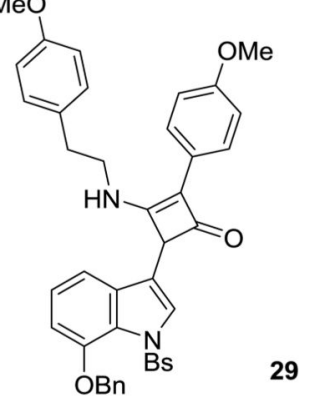

$\begin{array}{ccc}\text { entry }^{a} & \text { solvent } & \mathbf{2 9}: \mathbf{2 7}: \mathbf{2 2} \\ 1^{b} & \mathrm{Et}_{3} \mathrm{~N} & 1: 3: 94 \\ 2^{b} & \text { toluene } & 7: 26: 65 \\ 3^{c} & \text { MeCN } & 43: 25: 18 \\ 4^{c} & \text { neat } & 11: 50:- \\ 5^{c} & \text { DMF } & 71: 26:- \\ 6^{c} & \text { DMSO } & 79: 14:-\end{array}$

Scheme 2. Synthesis of the tyramine-substituted cyclobutenone ${ }^{a}$

${ }^{a}$ Reagents and conditions: $O$-methyltyramine (5 equiv), solvent, $36 \mathrm{~h}, 23{ }^{\circ} \mathrm{C} .{ }^{b} \mathrm{NMR}$ Integration ratio. ${ }^{C}$ Isolated yields. 
$\mathrm{MeO}$<smiles></smiles>

b. $\mathrm{NaH}$ $53 \%$<smiles>COc1ccc(CC(=O)Cl)cc1</smiles>

$\mathrm{MeO}$<smiles>COc1ccc(CCN(C(=O)Cc2ccc(OC)cc2)C2=C(c3ccc(OC)cc3)C(=O)C2c2c[R5](S(C)(=O)=O)c3c(OCc4ccccc4)cccc23)cc1</smiles>

c. $40^{\circ} \mathrm{C} \downarrow$ quant.
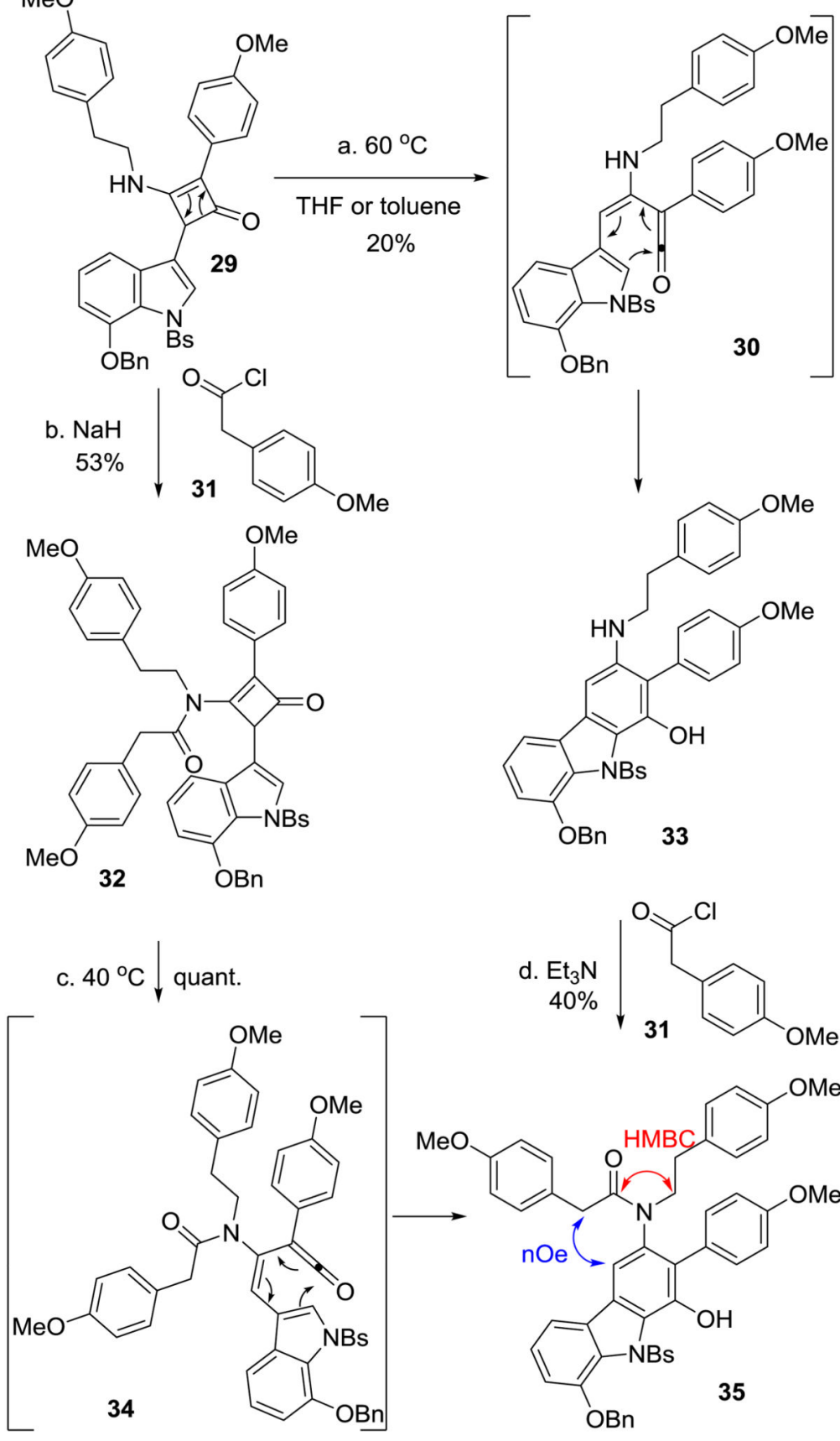

Scheme 3. Synthesis of acylated carbazole ${ }^{a}$

${ }^{a}$ Reagents and conditions: (a) THF or toluene, $60{ }^{\circ} \mathrm{C}$, overnight, 20\%; (b) $\mathrm{NaH}$ (1.1 equiv), 4-anisolyl acetic acid chloride (31, 1.1 equiv), THF, $-78{ }^{\circ} \mathrm{C}$ to r.t., $3-4 \mathrm{~h}, 53 \%$; (c) toluene, $40{ }^{\circ} \mathrm{C}$, overnight, quantitative yield; (d) $\mathrm{Et}_{3} \mathrm{~N}$ (2.0 equiv), 4-anisolyl acetic acid chloride (2.0 equiv), THF, $-78{ }^{\circ} \mathrm{C}$ to r.t., overnight, $40 \%$. 
<smiles></smiles>

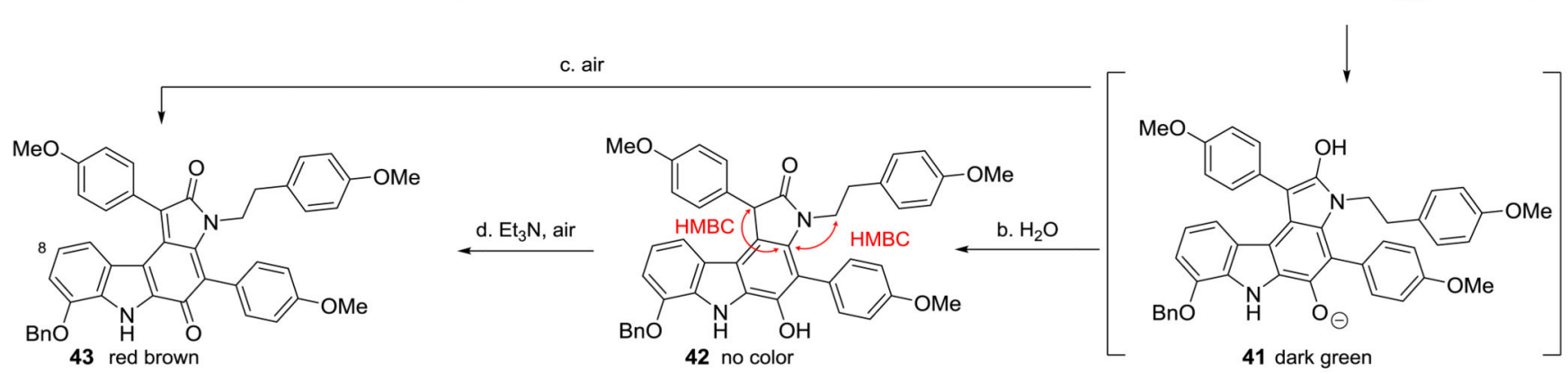

Scheme 4. Oxidative cyclization of anilide $35^{a}$

${ }^{a}$ Reagents and conditions: (a) LiHMDS (2.1 equiv), THF, $-78^{\circ} \mathrm{C}$ to r.t., $15 \mathrm{~min}$; (b) $\mathrm{H}_{2} \mathrm{O}$ (degas), r.t., $3 \mathrm{~min}, 62 \%$; (c) air, r.t., $10 \mathrm{~min}, 67 \%$; (d) $\mathrm{Et}_{3} \mathrm{~N}$ (5.0 equiv), $\mathrm{CH}_{2} \mathrm{CI}_{2}$, r.t., 1.5 h, quantitative yield. 

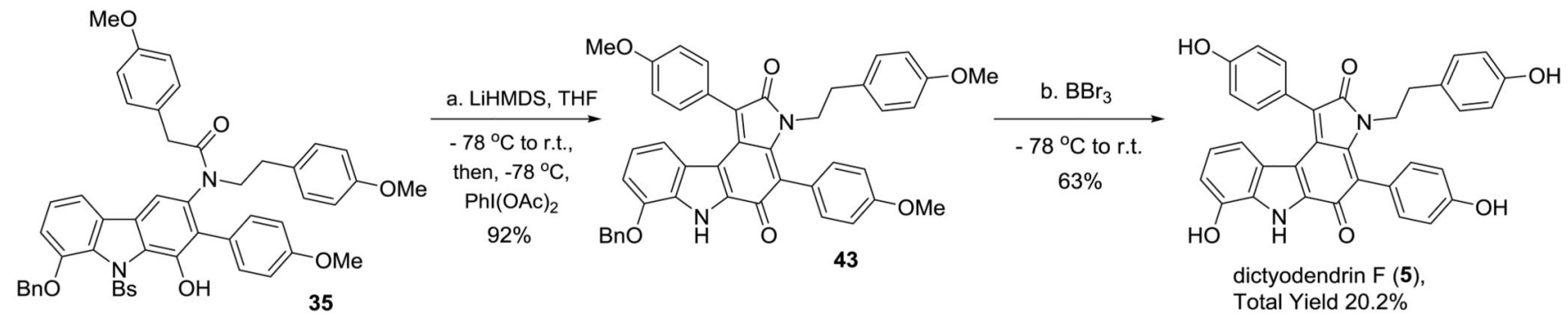

Scheme 5. Synthesis of dictyodendrin $\mathrm{F}^{a}$

${ }^{a}$ Reagents and conditions: (a) LiHMDS (2.1 equiv), THF, $-78^{\circ} \mathrm{C}$ to r.t., $15 \mathrm{~min}$, then,

$-78{ }^{\circ} \mathrm{C}$, Phi(OAc) $)_{2}$ (1.0 equiv), 20 min, THF 92\%; (b) $\mathrm{BBr}_{3}$ (100 equiv) $\mathrm{CH}_{2} \mathrm{CI}_{2},-78{ }^{\circ} \mathrm{C}$ to

r.t., overnight, $63 \%$. 
<smiles>COc1ccc(C2=C(OC(C)=O)C(c3c[nH]c4c(OCc5ccccc5)cccc34)C2=O)cc1</smiles><smiles>[X]c1cc(CCN)ccc1OC</smiles>

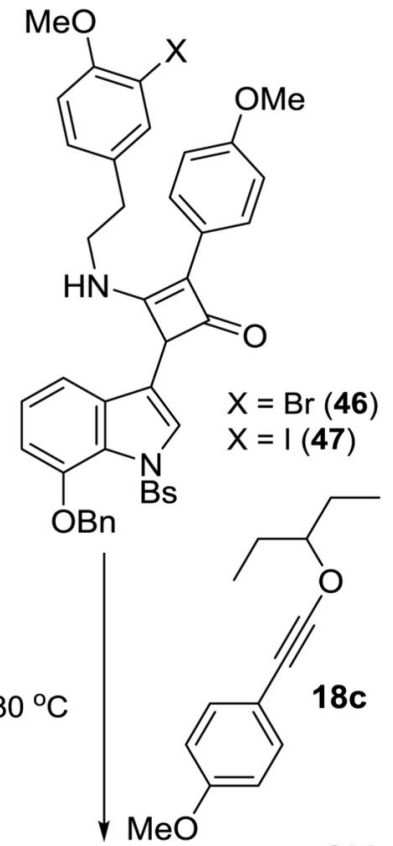

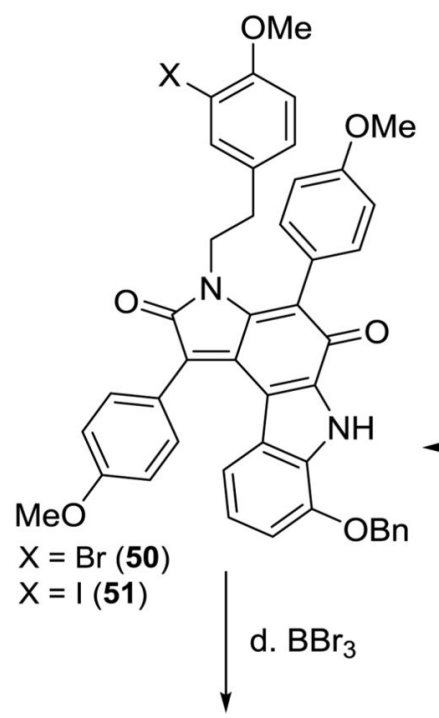

b. toluene, $80^{\circ} \mathrm{C}$

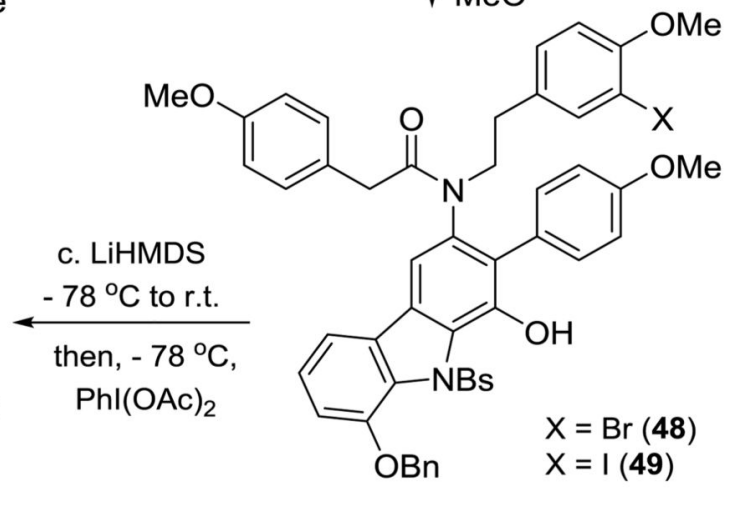<smiles></smiles>
$\mathrm{X}=\mathrm{Br}$, dictyodendrin $\mathrm{H}(\mathbf{6})$, Total Yield $11.9 \%$; $X=I$, dicytodendrin I (7), Total Yield 11\%.

Scheme 6. First total synthesis of dictyodendrins $\mathrm{H}$ and $\mathrm{I}^{\boldsymbol{a}}$ ${ }^{a}$ Reagents and conditions: (a) 44 or 45 (5.0 equiv), DMSO, r.t., 24-36 h, 73\% for 46 or $66 \%$ for 47; (b) $18 c$ (5-10 equiv), toluene, $80{ }^{\circ} \mathrm{C}, 12 \mathrm{~h}, 75 \%$ for $\mathbf{4 8}$ or $88 \%$ for $\mathbf{4 9}$; (c) LiHMDS (2.1 equiv), THF, $-78{ }^{\circ} \mathrm{C}$ to r.t., $15 \mathrm{~min}$, then, $-78{ }^{\circ} \mathrm{C}, \mathrm{Phl}(\mathrm{OAc})_{2}$ (1.0 equiv), $20 \mathrm{~min}, 79 \%$ for 50 or $62 \%$ for 51 ; (d) $\mathrm{BBr}_{3}$ (100 equiv), $\mathrm{CH}_{2} \mathrm{CI}_{2},-78{ }^{\circ} \mathrm{C}$ to r.t., overnight, $54 \%$ for dictyodendrin $\mathrm{H}(6)$ or $60 \%$ for dictyodendrin $\mathrm{I}(7)$ 
Table 1

Model study of the hetero-[2+2]-cycloaddition reaction of aryl ynol ethers

로을

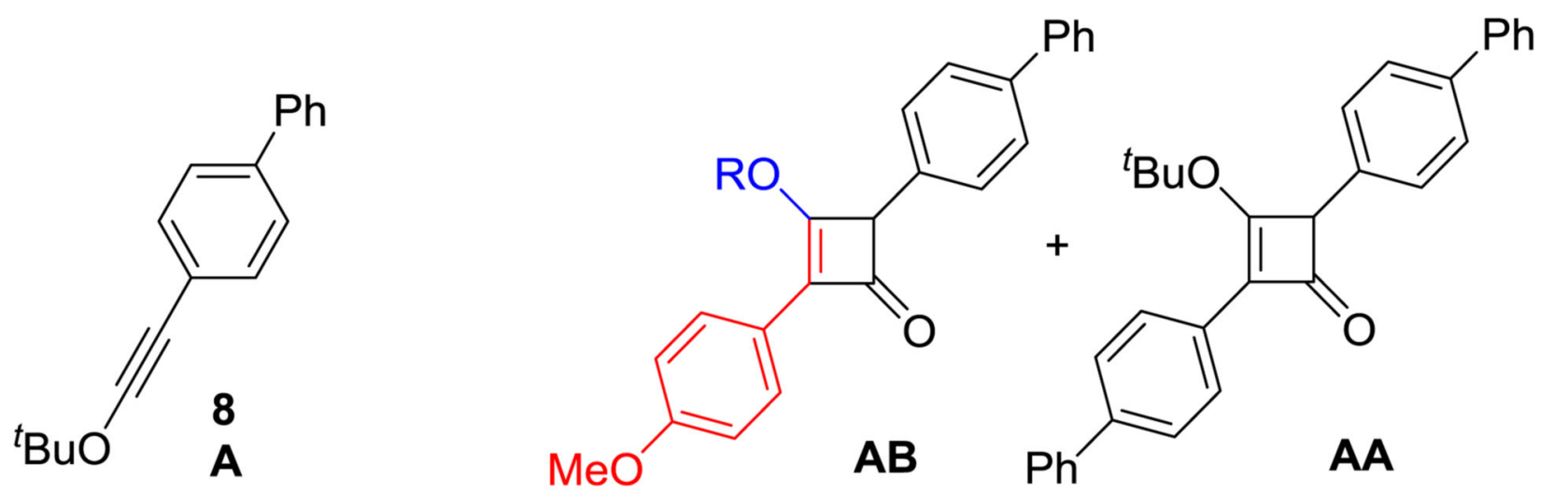

로을

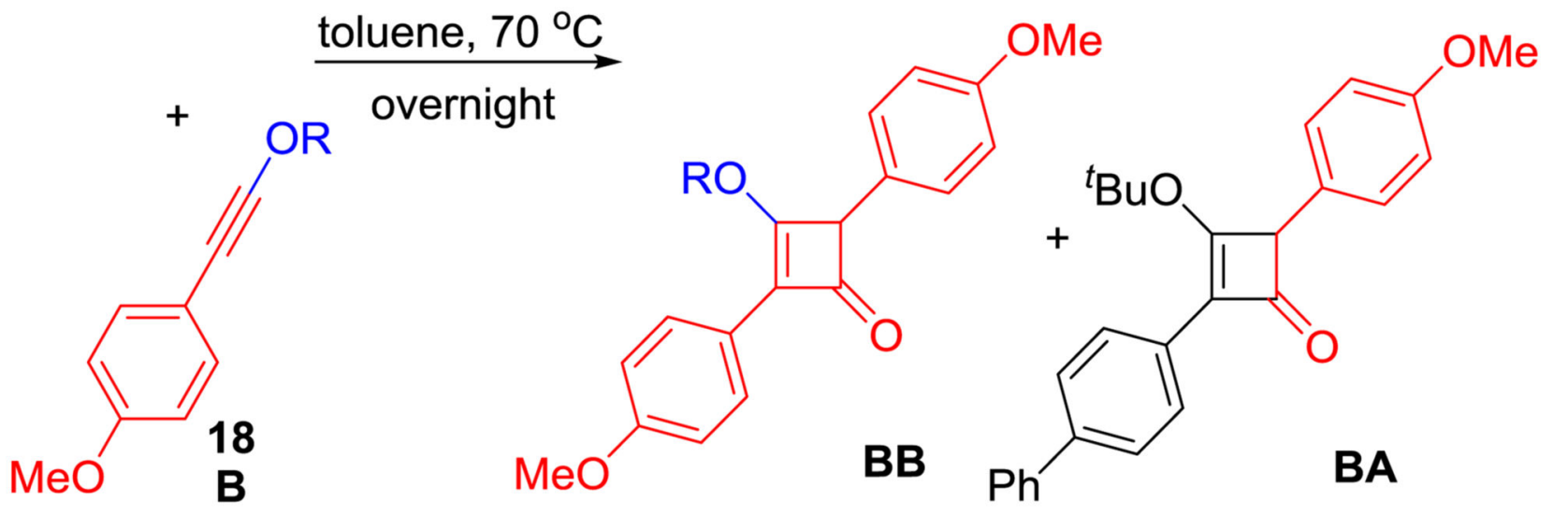

로을

entry $R \quad$ equiv $B \quad A B: A A: B B: B^{a}$

$1{ }^{t} \mathrm{Bu}(18 \mathrm{a}) \quad 0.5 \quad 1: 1: 0.25: 0.25$

$2{ }^{t} \mathrm{Bu} \quad 1.0 \quad 4: 1: 2.5: 1$

$3{ }^{t_{\mathrm{Bu}}} \quad 2.5 \quad 5: 1: 10: 1.5$

$4 \quad \mathrm{Ad}(18 \mathrm{~b}) \quad 0.5 \quad 3: 1: \mathrm{NA}: \mathrm{NA}$

5 Ad $\quad 1.0 \quad 8: 1:$ NA: NA

$6^{b}$ Ad $\quad 2.5 \quad 19: 1: \mathrm{NA}: \mathrm{NA}$

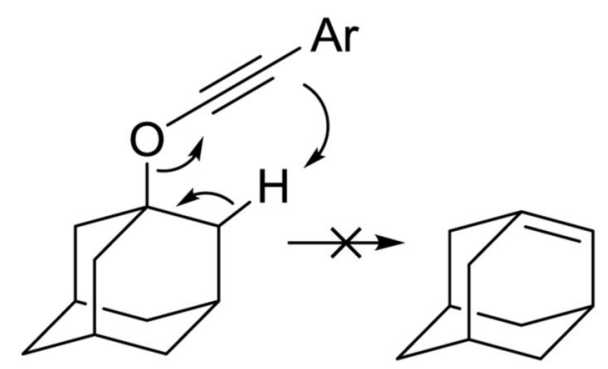

$18 b$

${ }^{a}$ crude ratio by ${ }^{1} \mathrm{H}$ NMR. ${ }^{b} 69 \%$ isolated yield of $A B$ 